dent. There are more Neanderthal features present, although some postcranial characters may well turn out to be more widespread plesiomorphies when data from other, non-Neanderthal, samples are known ${ }^{8,9}$. But the presence of characters such as midfacial projection and an incipient suprainiac fossa does seem

TABLE 2. Some character distributions in the Atapuerca sample

\begin{tabular}{|c|c|c|c|}
\hline & $\begin{array}{l}\text { Homo } \\
\text { erectus }\end{array}$ & Neanderthal & $\begin{array}{l}\text { Homo } \\
\text { sapiens }\end{array}$ \\
\hline $\begin{array}{l}\text { 1. Vault broadest } \\
\text { near base }\end{array}$ & & & \\
\hline $\begin{array}{l}\text { 2. High total } \\
\text { prognathism }\end{array}$ & $\checkmark$ & & \\
\hline $\begin{array}{l}\text { 3. Laterally thick } \\
\text { supr. torus }\end{array}$ & $\checkmark$ & & \\
\hline $\begin{array}{l}\text { 4. Mandibular } \\
\text { morphology }\end{array}$ & $\checkmark$ & $\checkmark$ & \\
\hline $\begin{array}{l}\text { 5. Lower limb } \\
\text { robusticity }\end{array}$ & $\checkmark$ & $\checkmark$ & \\
\hline $\begin{array}{l}\text { 6. Cranial capacity } \\
\text { range }\end{array}$ & $\checkmark$ & $\checkmark$ & $\checkmark$ \\
\hline $\begin{array}{l}\text { 7. Shape of supr. } \\
\text { torus }\end{array}$ & & $\checkmark$ & \\
\hline $\begin{array}{l}\text { 8. Incip. suprainiac } \\
\text { fossa }\end{array}$ & & $\checkmark$ & \\
\hline $\begin{array}{l}\text { 9. Midfacial } \\
\text { projection }\end{array}$ & & $\checkmark$ & \\
\hline $\begin{array}{l}\text { 10. Lateral occipital } \\
\text { profile }\end{array}$ & & $\checkmark$ & $\checkmark$ \\
\hline $\begin{array}{l}\text { 11. Tympanic } \\
\text { morphology }\end{array}$ & & $\checkmark$ & $\checkmark$ \\
\hline $\begin{array}{l}\text { 12. High cranial } \\
\text { vault }\end{array}$ & & $\checkmark$ & $\checkmark$ \\
\hline $\begin{array}{l}\text { 13. Shape of temp. } \\
\text { squama }\end{array}$ & & & $\checkmark$ \\
\hline $\begin{array}{l}\text { 14. Rear parietal } \\
\text { profile }\end{array}$ & $\checkmark$ & & $\checkmark$ \\
\hline $\begin{array}{l}\text { 15. Adult occipmast. } \\
\text { morph. }\end{array}$ & & & $\checkmark$ \\
\hline
\end{tabular}

to point to a significant phylogenetic link with the Neanderthals, aligning the Atapuerca hominids with that clade (or species, if $H$. neanderthalensis is recognized)

What of variation in Middle Pleistocene specimens generally? My reasons for distinguishing the Petralona and Steinheim crania included their contrasting facial morphologies and very large size difference. However, the small Atapuerca cranium 5 shows clear facial resemblances to Petralona, while a larger facial fragment (AT-404) displays a resemblance to the cheek region of Steinheim. Size differences between crania 4 and 5 also approach those between Petralona and Steinheim. So although considerable differences remain between the Petralona and Steinheim crania in features such as vault thickness and occipital form, it seems feasible that they can both be regarded as extensions of the variation shown in the early Neanderthal population(s) sampled at Atapuerca.
In turn, more fragmentary finds such as those from Vértesszöllös (Hungary) and Bilzingsleben (Germany), regarded by some as representing $H$. erectus, may also be linked morphologically to the Petralona-Atapuerca group. This would lead to the further weakening of claims for the existence of $H$. erectus in Europe (Table 1,a). The new data also bear upon the concept of a separate species, $H$. heidelbergensis, in the Middle Pleistocene of Europe and Africa ${ }^{5,7}$ (Table 1,c). This concept sprang from the resemblances between European specimens such as Petralona and African crania such as Broken Hill, but it depended not only on a clear demarcation of the specimens from $H$. erectus and modern $H$. sapiens (still very defensible), but also on a demarcation from the Neanderthals. In the case of the European Middle Pleistocene representatives of $H$. heidelbergensis, this second distinction will be much more difficult to maintain following consideration of the variation present in the Atapuerca sample. It is difficult to envisage a suite of characters that could consistently differentiate specimens such as Mauer, Arago and Vértesszöllös from the primitive Neanderthals whose remains are concentrated in the 'Pit of the Bones' at Atapuerca. The Neanderthal lineage seems to have its roots deep in the Middle Pleistocene. For those such as myself, who believe the Neanderthal lineage was distinct from our own, this would mean that the origin of the $H$. sapiens clade was similarly ancient.

Chris Stringer is in the Human Origins Programme, Department of Palaeontology, Natural History Museum, Cromwell Road, London SW7 5BD, UK.

1. Arsuaga, J.-L., Martínez, 1., Gracia, A., Carretero, J.-M. \& Carbonell, E. Nature 362, 534-537 (1993).

Mellars, P. \& Stringer, C. (eds) The Human Revolution (Edinburgh University Press, 1989).

3. Bräuer, G. \& Smith. F. (eds) Continuity or Replacement? Controversies in Homo sapiens Evolution (Balkema Rotterdam, 1991)

4. Woipoff, M. J. hum. Evol. 9, 339-358 (1980)

5. Stringer, C. in Ancestors: The Hard Evidence (ed. Delson, E) 289-295 (Liss, New York, 1985).

Hublin, J in L'Homme de Néandertal. Vol. 3 L'Anatomie 81-94 (ERAUL, Liège, 1988)

7. Rightmire, G. P. The Evolution of Homo erectus (Cambridge University Press, 1990)

8. Trinkaus, E. in L'Homme de Néandertal. Vol. 3 L'Anatomie 11-29 (ERAUL, Liège, 1988).

9. Rak, Y. in Publication 14th Annual Spring Systematics Meeting (ed. Nitecki, M.) (Field Museum of Natural History, Chicago, in the press).

\section{A bid for pregnancy}

IMPORTANT blological objects, as Jim Watson remarked, come In pairs. For example, a woman has two ovaries. Yet every month, only one of them releases an ovum; the other holds back. How do they decide which of them is to do the Job that month?

One guess is that they work in strict altemation, perhaps in obedlence to a monthly nerve signal from the brain. This seems unlikely; nature is not usually so digltal. In any case, reproductlve physiology tends to use hormonal rather than nervous signals. Daedalus reckons that the ovaries compete for the monthly honour. Each sends out some sort of hormonal signal, while reading the corresponding signal sent out by the other. Llke two poker players, each raises Its level of hormonal bldding, untll one of them feels outbid, and folds. The victor then provides the ovum for that month.

This mechanism suggests a novel form of contraception. By Introducing false signals into the system, it should be possible to trick each ovary into thinking that the other has won the bldding. So DREADCO endocrinologists are taking a regular sequence of blood samples from a panel of female volunteers. They are looking for rapld fluctuations of usually neglected minor steroids during the bulld-up to ovulation. In these signals they hope to read the bidding and counter bidding of the two ovarles. The results could be quite complex and subtle. Each ovary may well prepare several potential ova each month, like a card player considering which card to play in the light of signals from the opposition. Once the team has cracked this bidding code, they should be able to subvert It. DREADCO's 'Anova' contraceptive will sllp a false hormonal bid into the system. It will convince each ovary that the other has won the trick. Both will then fold in defeat, and their owner will not become pregnant that month.

A single monthly pill or injection of Anova should work neatly, with no sideeffects. By preventing ovulation it may even suppress menstruation - a useful advantage, once the user has reallzed that it is not a sign of disastrous contraceptlve fallure. Furthermore, the same blochemistry might be adapted not to ellminate the chance of pregnancy, but to increase it. For would-be mothers, Daedalus hopes to develop 'Binova'. This inverse hormonal cocktall will be a sort of blochemical misère bid. It will convince each ovary that the other has folded. Both will therefore produce an ovum that month. Thls will double the subject's chance of pregnancy, and also give her a useful chance of bearing non-Identlcal twins. David Jones 